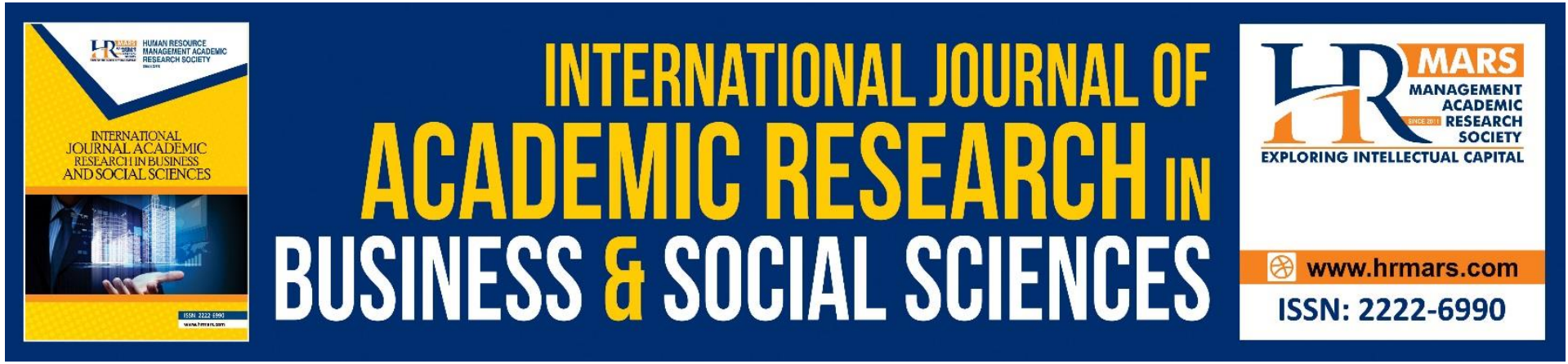

\title{
Factors Affecting Purchase Intention of Green Products among Households in Sarawak
}

Jocelyn Goh Swee Kee, Nur-Nadhira Baharuddin \& Rossazana Ab-Rahim

To Link this Article: http://dx.doi.org/10.6007/IJARBSS/v11-i8/10892 DOI:10.6007/IJARBSS/v11-i8/10892

Received: 12 June 2021, Revised: 16 July 2021, Accepted: 04 August 2021

Published Online: 27 August 2021

In-Text Citation: (Kee et al., 2021)

To Cite this Article: Kee, J. G. S., Baharuddin, N.-N., \& Ab-Rahim, R. (2021). Factors Affecting Purchase Intention of Green Products among Households in Sarawak. International Journal of Academic Research in Business and Social Sciences, 11(8), 1767-1779.

Copyright: (c) 2021 The Author(s)

Published by Human Resource Management Academic Research Society (www.hrmars.com)

This article is published under the Creative Commons Attribution (CC BY 4.0) license. Anyone may reproduce, distribute, translate and create derivative works of this article (for both commercial and non-commercial purposes), subject to full attribution to the original publication and authors. The full terms of this license may be seen at: http://creativecommons.org/licences/by/4.0/legalcode

Vol. 11, No. 8, 2021, Pg. 1767 - 1779

http://hrmars.com/index.php/pages/detail/IJARBSS

JOURNAL HOMEPAGE

Full Terms \& Conditions of access and use can be found at http://hrmars.com/index.php/pages/detail/publication-ethics 


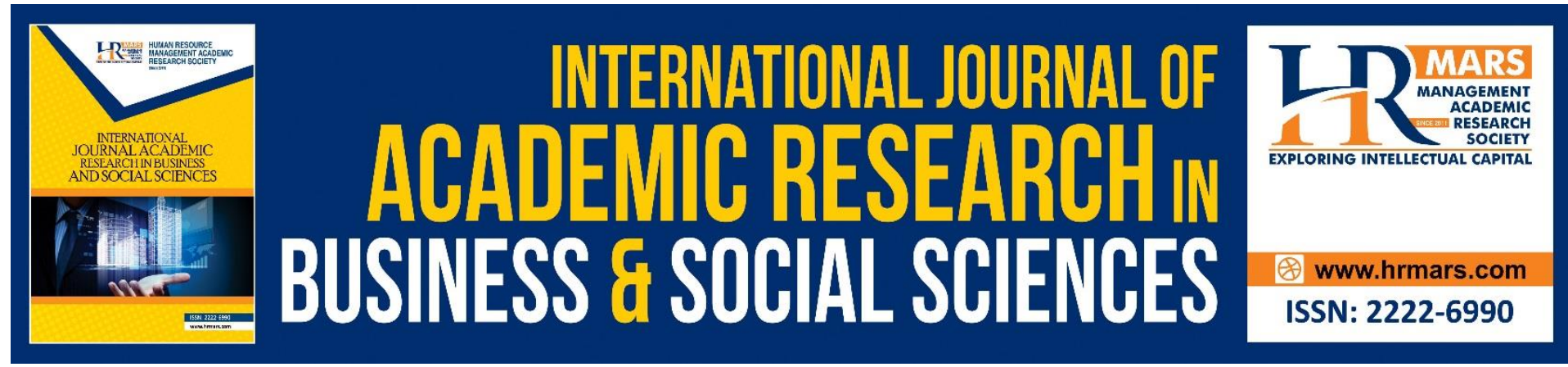

\title{
Factors Affecting Purchase Intention of Green Products among Households in Sarawak
}

\section{Jocelyn Goh Swee Kee, Nur-Nadhira Baharuddin \& Rossazana Ab-Rahim}

Faculty of Economics and Business, Universiti Malaysia Sarawak, Malaysia

Email: bnnadhira@unimas.my

\begin{abstract}
This study aims to investigate the factors affecting purchase intention of green products among households. Green products are segregated from normal products in the market, and it is interesting to know what the society really thinks of those products, and what affects their desire and intention to purchase the green products. This study provides a research on what green products are, how they help the environment, and what affects consumers' in the intention of buying these products. In this study, there are 2 specific objectives, including to examine the relationship between demographic factors and green purchasing intention, and assess factors affecting green purchasing intention. The methodologies which are used in this study includes multiple regression analysis and Pearson correlation test. The results of this study which concluded that demography, perceived value of products, and green branding are significant in affecting the purchase intention of green products serves as a guide for green product manufacturers on what is important to consumers in choosing products to buy.
\end{abstract}

Keywords: Purchase Intention, Green Products, Demography, Perceived Value of Product, Green Packaging, Green Branding, Green Marketing

\section{Introduction}

In the current times, environmental ethics is a significant topic among corporations and consumers alike. The withering of Mother Nature has brought into light the topic of environment conservation and preservation, which later brought about a new form of consumer ethics called green consumerism (Moisander, 2007). Deterioration of the environment and its effects on human life are among the issues of high importance which gained much attention from world organization, governmental bodies, and scholars (Haytko \& Matulich, 2008). In the past decades, there is a steep decline of natural resources and serious destruction of the environment, due to the increase of goods and services consumptions by consumers, leading to damaging consequences such as pollution and extinction of animals and plants, as well as global warming (Chen \& Chai, 2010). The increased consciousness towards the environment have changed the demand and purchasing patterns of products that are deem to be beneficial to the environment, and how consumers behave (Medelson \& Polonsky, 1995). The interest towards issues pertaining the environment has faced increase due to frequent exposure by the media and increased awareness towards 
pollution issues, as well as activism in environmental issues and occurrence of major industrial disasters (Kalafatis et al., 1999).

The state of the environment relies greatly on how humans behave (Steg \& Vlek, 2009), as it can significantly destroy the earth and eventually endanger the lives of humans and other living organisms (Lehman \& Geller, 2004). The out-of-the-ordinary changes of climate and the environment became factors that influence consumer behaviour to act 'green' in their purchasing (Paco \& Raposo, 2009; Okada \& Mais, 2010), which in turn increases significantly the demand for products that benefits the environment, or green products (Dangelico \& Pontrandolfo, 2010).

Due to these factors, households started taking the issue of environmental protection and conservation as a factor that affects their purchasing behaviour as there is an increase awareness regarding the common responsibility of conserving the nature and it is not just the responsibilities of the government bodies' or corporations (Fraj-Andres \& Martinez, 2006). With this increased awareness, the concept of green purchasing becomes a trend in the market. Consumers in first world countries see this as one of the important factors in making any purchasing decision (Peattie \& Charter, 1992). Green consumption is a concept related to sustainable use of goods and services, where users of such goods and services take into account the impact of the usage towards the environment or nature (Moisander, 2007).

Green products are goods that contains no harm towards the environment, the atmosphere, and human health. The OECD, or Organization for Economic Cooperation and Development, set out a definition of green products as goods that can thwart and cut down on damage towards the environment. Within the environment, contains soil, water, air, waste, ecosystem, and noise (Monkelbaan, 2011). According to Calkins (2008), there is an increase in the manufacturing and producing of products that are not harmful to the environment, these products contain materials that are low in toxic, and has recyclability. These products are good for the environment during the process of production and also during disposal (Akbar, 2014). In Malaysia, awareness towards green products can be consider as moderate, with a handful of companies offering green products and services such as consultation for green buildings, manufacturing of biodegradable cleaners and coatings, innovation of stormwater channelling and water filtration equipment, as well as products catered for landfills (Expert Environmental, n.d.). In Sarawak, many great efforts are done to introduce green products to the society, such as the use of Hydrogen buses as a public transport, introduction of biodegradable packaging and reusable shopping bags (BorneoTalk, 2020). To further support this effort, Shell Malaysia also offered the certificate of Renewable Energy or REC to any cooperate purchase of renewable energy generated in Sarawak (Shell, 2019). Many supermarkets and department stores are also purchasing biodegradable plastic bags and packaging for their usage in delivering the products sold in their stores, and the use of biodegradable food packaging are widely used in Sarawak. There has also been increase in the use of electric vehicles charging ports in malls since there are more electric vehicles on the road in Sarawak (Lau, 2017).

\section{Past Studies}

According to Abdul Rahim, Sulaiman, Thoo, Mohd Arif and Abdul Hamid (2017), demography has a certain significance towards the purchasing intention of green products. The variables used by this research was gender, age, education level, and income level. The researchers used the Cronbach's alpha coefficient test to test the reliability of the variables used, while independent t-test and ANOVA test was used in the research process to arrive at the results 
and conclusion. The results of the research showed that gender does possess significance influence in the decision of purchasing green products, where females generally have more intention of buying such products compared to males. Other factors such as age, education level, and income level does not have much effect on the green purchase intention among consumers. The research concluded that green products are accepted regardless of consumer's backgrounds due to the strong marketing of green products and the popularity of such products itself.

According to another study by Kong, Harun, Sulong, and Lily (2014), using the factor analysis and multiple regression analysis it was found that perceived value of green product has significance and positive influence against the purchasing intention of such product. Therefore, the research suggested that corporations should emphasis on the performance of their green products to reach the expectations of the perceived value of consumers or even exceed those expectations in order to retain its sales. In the same research by Kong et al. (2014), knowledge about green packaging has a positive relation with the purchasing intention of green products. The more the knowledge regarding green packaging, the more positive the attitude towards green products, the higher the purchasing intention for products that contain the green packaging.

In a research by Huang and Yang (2013), it was found through the correlation tests that green branding has a positive and significant relationship with green purchasing intentions. The green branding will lead to even more knowledge in green brand and better attitude towards the products thus eventually lead to a higher level of green purchasing intention. According to Ansar (2013), it was found that green advertisements or green marketing has a moderate positive relation with green purchasing intentions.

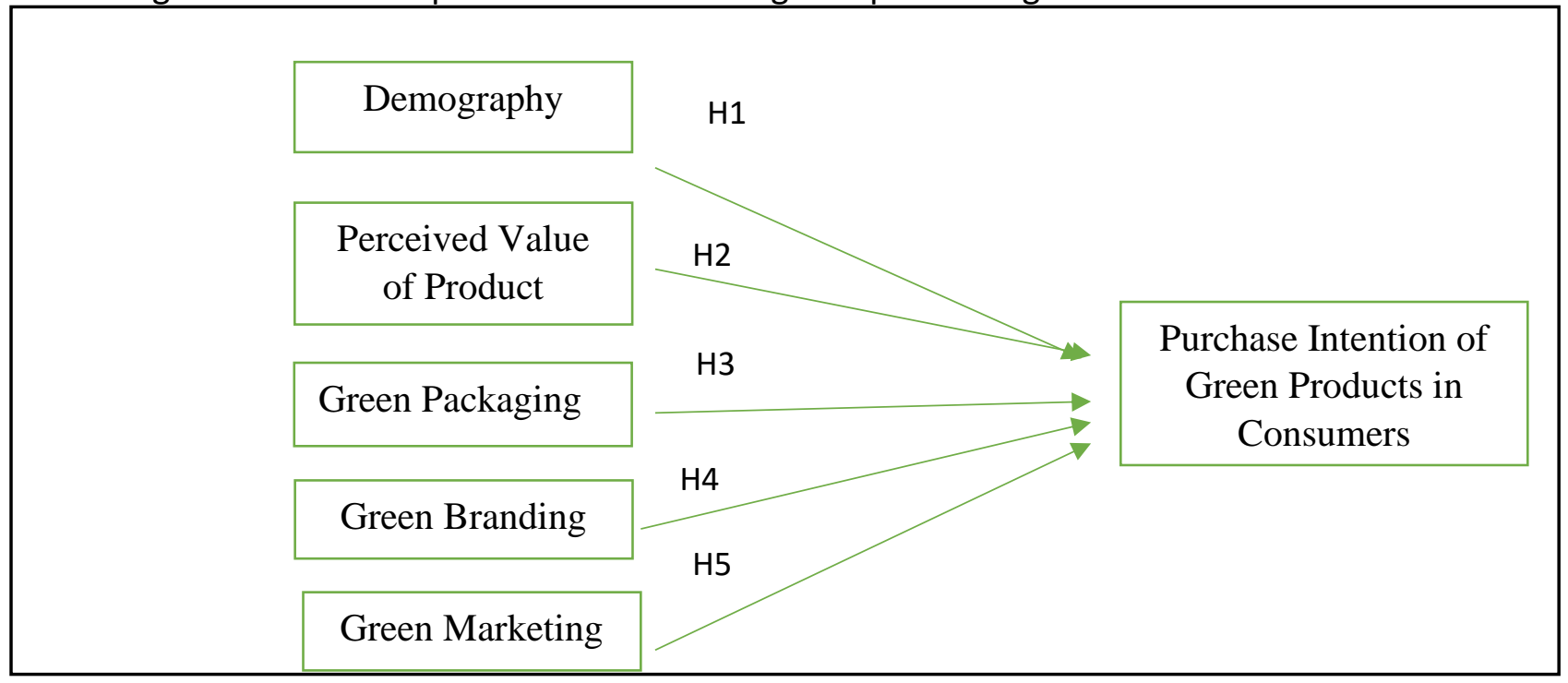

Figure 1. Conceptual Model of Factors Affecting Purchase Intention of Green Products

The main purpose of this study is to estimates the factors affecting the purchase intention of green products among households in Sarawak. Based on the theoretical framework stated above, this study is focusing on five different independent variables that specifically selected based on the common variables used in the previous literature i.e. Demography, Perceived Value of Product, Green Packaging, Green Banding and Green Marketing (see: Abdul Rahim (2017), Mahesh (2013), Morel \& Kwakye (2012), Huang \& Yang (2013), Ansar (2013)) 


\section{Data and Methodology \\ Research Design}

Research design provides the outlines in producing the proofs in accordance to a certain criteria and the research questions that the researcher wants to answer (Bryman \& Bell, 2007). A quantitative research is one where numerical measurements and analysis are conducted to arrive upon a finding (Zikmund et al., 2010). It is also defined as the gathering of data that involves large number of samples and numerical calculation of such results (Wiid \& Diggines, 2010). Data derived from quantitative means are essential for hypothesis setting and statistics computation and calculations to find out the relationship between the independent variables and the dependent variable. A quantitative research is suitable for this study as inferential statistics which helps determine the accuracy of hypotheses is without any bias and it helps with accurate analysis of the factors. Through this, a deductive step can be done to narrow down reasoning behind the dependent variable (Bryman \& Bell, 2011).

However, a quantitative research is not without criticisms. It is said that a quantitative research can have inaccurate results as each respondent react to questions differently. They each might have a different knowledge and understanding about the questions asked, which will lead to different answers compared to what they actually think. Also, a quantitative research is based on the 'what-ifs' where in real life situations, respondents might make a totally different choice. Their answers can also depend on what they think in the current situation and current mood (Bryman \& Bell, 2011).

This study adopts the cross-sectional research design, where at one point of time, quantitative data on more than one case relating to two or more variables will be collected (Bryman \& Bell, 2007). Quantitative data is used to determine the relationship between demography, perceived value of product, green packaging, branding, and marketing, as well as the purchase intention towards green products among consumers. The research type that is used in this study is the descriptive research. A descriptive research is used to narrowly describe a situation which can answer various questions. It uses scientific measures and methodology to gather data and make up a data structure that can explain the features of a target sample (Hair, Bush, Ortinau, \& Shiu, 2009). In this descriptive type study, questionnaires which helps identify the factors of demography, perceived value of product, green packaging, as well as green branding and green marketing, and the purchasing intention of green products among consumers were distributed. Framework and hypotheses are tested out to produce link between the variables studied and the green purchasing decisions among the consumers.

\section{Data Collection}

Primary data is collected directly by a researcher in accordance to their own standards. Common collection methods are questionnaires, interviews, case studies, or observations (Ajayi, 2017). It is done on target respondents that the researcher aimed for. In this study, the primary data are collected through questionnaires. Questionnaires will allow for accuracy and reliability of study as a random sample can be used to identify the general perception of the public regarding the topic. The questionnaire was done via Google Form and distributed electronically through online messaging tools or social media. This study also utilizes the secondary data available to test the hypotheses. Secondary data is one that has undergone reconstruction or analysis of other researchers such as journal articles, conference papers, books, and publications (Ajayi, 2017). In this study, secondary data is used as a base in doing the literature review and theoretical review needed, and enable a proper research framework 
to be created. For data analysis purposes, SPSS programme was used to analyse the data collected from 100 respondents, and Microsoft Word was used to describe the analysis conducted.

\section{Results and Discussion}

\section{Descriptive Statistics}

Among the 100 respondents, $54 \%$ are female while the rest are male respondents from Sarawak. $46 \%$ of them are between the age of 22 to 30 years old while only $3 \%$ of the respondent age above 61 years old. More than half of the selected respondents have either Degree or Diploma as their highest level of education with different profession background including business owner, finance, education and healthcare. Due to only $4 \%$ of the respondents were retired individuals, majority of the them falls in the income bracket above the minimum wage in Malaysia. With only 9\% of respondents earn below RM1,200 and another $10 \%$ earning above RM6,501 per month.

The overall summary of the demographics of respondents in this study is as below:

Table 1. Respondents' Demography

\begin{tabular}{|c|c|c|c|}
\hline Demographic Variable & Description & Frequency & Percentage (\%) \\
\hline \multirow[t]{2}{*}{ Gender } & Male & 46 & 46 \\
\hline & Female & 54 & 54 \\
\hline \multirow[t]{6}{*}{ Age } & $18-21$ years old & 7 & 7 \\
\hline & 22-30 years old & 46 & 46 \\
\hline & $31-40$ years old & 20 & 20 \\
\hline & $41-50$ years old & 13 & 13 \\
\hline & $51-60$ years old & 11 & 11 \\
\hline & 61 years old \& above & 3 & 3 \\
\hline \multirow[t]{7}{*}{ Highest education level } & SPM & 25 & 25 \\
\hline & STPM & 2 & 2 \\
\hline & Diploma & 29 & 29 \\
\hline & Degree & 34 & 34 \\
\hline & Masters Degree & 4 & 4 \\
\hline & $\mathrm{PhD}$ & 1 & 1 \\
\hline & Other & 5 & 5 \\
\hline \multirow[t]{10}{*}{ Sector of Profession } & Business Owner & 10 & 10 \\
\hline & Service & 13 & 13 \\
\hline & Finance & 11 & 11 \\
\hline & Education & 11 & 11 \\
\hline & Engineering & 6 & 6 \\
\hline & Manufacturing & 5 & 5 \\
\hline & Healthcare & 6 & 6 \\
\hline & Insurance & 4 & 4 \\
\hline & Retired & 4 & 4 \\
\hline & Other & 30 & 30 \\
\hline
\end{tabular}




$\begin{array}{clll}\text { Monthly Income Level } & \text { Below RM1,200 } & 9 & 9 \\ & \text { RM1,201-RM2,500 } & 15 & 15 \\ & \text { RM2,501-RM3,500 } & 28 & 28 \\ \text { RM3,501-RM4,500 } & 16 & 16 \\ \text { RM4,501-RM5,500 } & 15 & 15 \\ \text { RM5,501-RM6,500 } & 7 & 7 \\ \text { RM6,501 \& above } & 10 & 10\end{array}$

\section{Multiple Regression Analysis}

Multiple regression analysis is done to find out the strength of the variables that an independent variable holds against a dependent variable. In this study, this analysis is used to analyze the factors that influences the purchase intention of green products among consumers in Sarawak, Malaysia.

Table 2. Model Summary: Multiple Regression Analysis ${ }^{b}$

\begin{tabular}{|c|c|c|c|c|c|}
\hline Model & $\mathrm{R}$ & R Square & $\begin{array}{l}\text { Adjusted } \\
\text { Square }\end{array}$ & $\mathrm{R}$ & $\begin{array}{l}\text { Std. Error of } \\
\text { the Estimate }\end{array}$ \\
\hline 1 & $0.872^{a}$ & 0.760 & 0.747 & & 1.63309 \\
\hline
\end{tabular}

a. Predictors: (Constant), Green Marketing, Demography, Perceived Value of Product, Green Branding, Green Packaging

b. Dependent Variable: Purchase Intention

Table 2 above shows the summary of the multiple regression analysis of all the variables, with purchase intention being the dependent variable. From the findings, the value of $R$ is 0.872 and $R^{2}$ is 0.760 . This means the dependent variable which is purchase intention of green products among consumers in Sarawak, Malaysia is $76 \%$ influenced by the independent variables of demography, perceived value of product, green packaging, green branding, and green marketing. The rest of the percentage are due to other factors outside of those outlined.

Table 3. ANOVA: Multiple Regression Analysis ${ }^{a}$

\begin{tabular}{|c|c|c|c|c|c|c|}
\hline Model & & $\begin{array}{l}\text { Sum of } \\
\text { Squares }\end{array}$ & $d f$ & $\begin{array}{l}\text { Mean } \\
\text { square }\end{array}$ & $\mathrm{F}$ & Sig. \\
\hline \multirow[t]{3}{*}{1} & Regression & 794.545 & 5 & 158.909 & 59.584 & $0.000^{b}$ \\
\hline & Residual & 250.695 & 94 & 2.667 & & \\
\hline & Total & 1045.240 & 99 & & & \\
\hline
\end{tabular}

a. Dependent Variable: Purchase Intention

b. Predictors: (Constant), Green Marketing, Demography, Perceived Value of Product, Green Branding, Green Packaging

Table 3 above shows the ANOVA results of multiple regression of all the variables, with purchase intention being the dependent variable. From the findings, the F-value of the analysis is 59.584 and significance or $p$-value is 0.000 , which is less than the significance level of 0.01 . When the $p$-value is less than 0.01 , the null hypothesis is rejected, and it signifies that all 5 independent variables have influence on the dependent variable of purchase intention of green products among consumers in Sarawak, Malaysia. 
Table 4. Coefficient: Multiple Regression Analysis ${ }^{a}$

\begin{tabular}{|c|c|c|c|c|c|c|}
\hline \multirow[b]{2}{*}{ Model } & & \multicolumn{2}{|c|}{$\begin{array}{l}\text { Unstandardized } \\
\text { Coefficients }\end{array}$} & \multicolumn{3}{|c|}{$\begin{array}{l}\text { Standardized } \\
\text { Coefficients }\end{array}$} \\
\hline & & $B$ & Std. Error & Beta & $T$ & Sig. \\
\hline \multirow[t]{7}{*}{1} & (Constant) & -1.115 & 1.157 & & - & 0.338 \\
\hline & & & & & 0.964 & \\
\hline & $\begin{array}{l}\text { Demography (Age, } \\
\text { highest education level, } \\
\text { monthly income level) }\end{array}$ & 0.206 & 0.057 & 0.207 & 3.600 & 0.001 \\
\hline & $\begin{array}{l}\text { Perceived Value of } \\
\text { Product }\end{array}$ & 0.376 & 0.091 & 0.340 & 4.127 & 0.000 \\
\hline & Green Packaging & -0.004 & 0.108 & -0.033 & $\begin{array}{l}- \\
0.033\end{array}$ & 0.973 \\
\hline & Green Branding & 0.398 & 0.098 & 0.361 & 4.054 & 0.000 \\
\hline & Green Marketing & 0.134 & 0.99 & 0.132 & 1.359 & 0.177 \\
\hline
\end{tabular}

a. Dependent Variable: Purchase Intention

Table 4 above shows the beta values and the interpretation of every mean independent variables which affect the dependent variable of purchase intention of green products. According to the analysis, green branding has the highest beta at 0.361 with a standard error rate of 0.098 , which can be translated as there are $9.8 \%$ of variations within the purchase intention of green products among consumers in Sarawak were caused by green branding. The independent variable of green branding is the most significant factor in affecting the purchase intention of green products, followed by perceived value of products, demography, green marketing, and green packaging, with coefficients of $0.398,0.376,0.206,0.134$, and 0.004 respectively. 
Results

Table 5. Hypotheses Findings

\begin{tabular}{|c|c|c|c|}
\hline Hypotheses & Statistical Tests ran & $\begin{array}{c}p- \\
\text { value }\end{array}$ & Significance \\
\hline $\begin{array}{l}\mathrm{H}_{1}: \quad \text { Demography significantly } \\
\text { affects purchase intention of green } \\
\text { products among households. }\end{array}$ & $\begin{array}{c}\text { Multiple Regression } \\
\text { Analysis }\end{array}$ & 0.001 & $\begin{array}{c}\text { Significant } \\
(p=0.001<0.05)\end{array}$ \\
\hline $\begin{array}{l}\mathrm{H}_{2} \text { : Perceived value of products } \\
\text { significantly affects purchase } \\
\text { intention of green products among } \\
\text { households. }\end{array}$ & $\begin{array}{c}\text { Multiple Regression } \\
\text { Analysis }\end{array}$ & 0.000 & $\begin{array}{c}\text { Significant } \\
(p=0.000<0.05)\end{array}$ \\
\hline $\begin{array}{l}\mathrm{H}_{3}: \text { Green packaging significantly } \\
\text { affects purchase intention of green } \\
\text { products among households. }\end{array}$ & $\begin{array}{c}\text { Multiple Regression } \\
\text { Analysis }\end{array}$ & 0.973 & $\begin{array}{l}\text { Not significant } \\
(p=0.973>0.05)\end{array}$ \\
\hline $\begin{array}{l}\mathrm{H}_{4}: \text { Green branding significantly } \\
\text { affects purchase intention of green } \\
\text { products among households. }\end{array}$ & $\begin{array}{c}\text { Multiple Regression } \\
\text { Analysis }\end{array}$ & 0.000 & $\begin{array}{c}\text { Significant } \\
(p=0.000<0.05)\end{array}$ \\
\hline $\begin{array}{l}\mathrm{H}_{5} \text { : Green marketing significantly } \\
\text { affects purchase intention of green } \\
\text { products among households. }\end{array}$ & $\begin{array}{c}\text { Multiple Regression } \\
\text { Analysis }\end{array}$ & 0.177 & $\begin{array}{l}\text { Not significant } \\
(p=0.177>0.05)\end{array}$ \\
\hline
\end{tabular}

Referring to Table 5, three of the variables were estimated to have a significant affect towards the purchase intention of green products among the households in Sarawak. The demography (age, education level, income level, etc.), the perceived value of products and green branding all have the significant $p$-value. The results of this study is parallel with other studies for the independent variables. Firstly, for demography, it was found that age, education level, and income level plays a part in affecting the purchase intention of green products among households significantly, which shows the same results as study done by Wang, Wong, and Narayanan (2019) which concluded that education affects green purchase intentions where consumers with higher education level tend to lead to higher purchase intentions of green products. Study done by Che In and Ahmad (2018) estimated that age and level of income has differing effects on green purchasing intentions.

Other than demography, the conclusion that perceived value of product influences green purchase intention positively was also met by Doszhanov and Ahmad (2015), Kong et al. (2014), as well as Dhewi, Adi Putra, Soeharto, and Wahyudi in 2018. This study also concluded that green branding places significance in consumers' intention to purchase green products, which was priory agreed by Huang and Yang in a study published in 2013. 
Pearson Correlation Test

Table 6. Pearson Correlation: Summary

\begin{tabular}{|c|c|c|c|c|}
\hline $\begin{array}{l}\text { Independent } \\
\text { Variables }\end{array}$ & $\begin{array}{l}\text { Pearson } \\
\text { Correlation }\end{array}$ & $\begin{array}{l}\text { Sig. (2- } \\
\text { tailed) }\end{array}$ & Interpretation & Significance \\
\hline Demography & $0.555^{* *}$ & 0.000 & $\begin{array}{l}\text { Moderate positive } \\
\text { correlation }\end{array}$ & Significant \\
\hline $\begin{array}{l}\text { Perceived value of } \\
\text { product }\end{array}$ & $0.789 * *$ & 0.000 & $\begin{array}{l}\text { Strong positive } \\
\text { correlation }\end{array}$ & Significant \\
\hline Green Packaging & $0.707 * *$ & 0.000 & $\begin{array}{l}\text { Strong positive } \\
\text { correlation }\end{array}$ & Significant \\
\hline Green Branding & $0.782 * *$ & 0.000 & $\begin{array}{l}\text { Strong positive } \\
\text { correlation }\end{array}$ & Significant \\
\hline Green Marketing & $0.732 * *$ & 0.000 & $\begin{array}{l}\text { Strong positive } \\
\text { correlation }\end{array}$ & Significant \\
\hline
\end{tabular}

** Correlation is significant at the 0.01 level (2-tailed).

Referring to Table 6, all of the variables observed have significant estimations over the purchase intention of households in Sarawak. According to Meghanathan (2016), Pearson coefficient estimated between 0.60 to 0.79 signifies that there is a strong positive relationship between the estimated variables. Therefore, variables such as perceived value of product, packaging, branding and marketing were estimated to have a strong and positive correlation with the dependent variable with perceived value of product having the highest level of correlation at 0.789 . Meanwhile demographic elements only poised a moderate but still positive correlation with the purchase intention of green products in Sarawak. The relationship between demography and purchase intention is significant at 0.01 level.

\section{Conclusion}

From this study, it is estimated that households in Sarawak are more price sensitive in terms of green products purchasing. Incentives and policy implementations from the government should be emphasis especially towards improving the perceived value of green products in comparison to the normal goods and services available in the market. Producers should be encouraged to adopt a sustainable process especially in their products' packaging, branding and manufacturing through continuous support from the government. The continuous campaign and knowledge-sharing activity will contribute to the improvement of the level of awareness among the consumers thus prompting the purchase intention of the green products. Unfortunately, households tend to waver in face of paying more for a green product despite all the benefits that can be derived from the usage. If environmental benefits outweigh the profit-earning component in long term, it is considerable for green products to be placed at the same pricing as normal products in order to encourage the use of green products for the better sustainability of the earth.

Over the years as we are faced with demanding challenges, both from the economic perspective and environmental perspective, green growth has become a new trend that governments across the globe have been putting their efforts in. This is a positive change as it will push the economic development in the direction that is more sustainable for our environment, and it promotes a more responsible use of energy and utilisation of natural resources. Green growth offers a door out for developing economies to grow economically without sacrificing the environment, as economic growth can now be tied with sustainable 
choices in use of energy and water, or other natural resources. The governments of developing economies have pondered upon the possibilities and opportunities brought upon by this change and how they could work around it, with possible initiatives such as green taxes, carbon credits, green funds and loans, renewable energy certificates and subsidies.

\section{References}

Abdul Rahim, R., Sulaiman, Z., Thoo, A., Arif, M., \& Abdul Hamid, M. (2017). Consumers' demographic profile influence on green purchase intention. doi:10.1088/1757899X/215/1/012020

Ajayi, V. O. (2017). Primary Sources of Data and Secondary Sources of Data. doi:10.13140/RG.2.2.24292.68481

Akbar, W., Hassan, S., Khurshid, S., Niaz, M., \& Rizwan, M. (2014). Antecedents affecting customer's purchase intention towards green products. Journal of Sociological Research, 5(1). doi:10.5296/jsr.v5i1.6566

Ansar, N. (2013). Impact of green marketing on consumer purchase intention. Mediterranean Journal of Social Sciences, 4(11). doi:10.5901/mjss.2013.v4n11p650

BorneoTalk. (2020). Towards an eco-friendly Sarawak. Retrieved from BorneoTalk: https://www.borneotalk.com/towards-an-eco-friendly-sarawak/

Bryman, A., \& Bell, E. (2007). Business Research Methods. Oxford University Press.

Bryman, A., \& Bell, E. (2011). Business Research Methods. In 3 (Ed.). Oxford University Press.

Calkins, M. (2008). Materials for sustainable cities: A complete guide to the evaluation, selection, and use of sustainable construction materials mining the built environment. Landscape Architecture, 98(12), 68-71.

Che In, F., \& Ahmad, A. Z. (2018). The effect of demographic factors on consumer intention to purchase green personal care products. Proceeding of INSIGHT 2018 1st International Conference on Religion, Social Sciences and Technological Education. 1st International Conference on Religion, Social Sciences and Technological Education.

Chen, T., \& Chai, L. (2010). Attitude towards the environment and green products: Consumers' perspective. Management science and engineering, 4(2), 27-

39.doi:10.3968/j.mse.1913035X20100402.002

Dangelico, R. M., \& Pontrandolfo, P. (2010). From green product definitions and classifications to the Green Option Matrix. Journal of Cleaner Production, 18(16-17), 1608-1628. doi:10.1016/j.jclepro.2010.07.007

Dhewi, S. T., Adi Putra, W. J., Soeharto, \& Wahyudi, H. D. (2018). The influence of green perceived value and green perceived risk perceptions on the green product purchase intention. The First International Research Conference on Economics and Business (IRCEB), (pp. 411-425). doi:10.18502/kss.v3i3.1899

Doszhanov, A., \& Ahmad, Z. A. (2015). Customers' intention to use green products: The impact of green brand dimensions and green perceived value. SHS Web of Conferences. doi:10.1051/shsconf/20151801008

Expert Environmental. (n.d.). Green Product Companies in Malaysia. Retrieved from Expert Environmental: https://www.environmental-expert.com/companies/keyword-greenproduct-15424/location-malaysia

Fraj-Andres, E., \& Martinez, E. (2006). Ecological consumer behaviour: An empirical analysis. International IJC, 31(1), 26-33. doi:10.1111/j.1470-6431.2006.00565.x

Hair, J. F., Bush, R. P., Ortinau, D. J., \& Shiu, E. (2009). Marketing Research (European ed.). McGraw-Hill Higher Education. 
Huang, Y.-C., \& Yang, M. (2013). Effects of green brand on green purchase intention. Marketing Intelligence \& Planning, 32(3), 250-268. doi:10.1108/MIP-10-2012-0105

Haytko, D. L., \& Matulich, E. (2008). Green-advertising and environmentally responsively consumer behaviours: Linkages examined. Journal of Management and Marketing Research, 1, 5-14. doi:10.1.1.582.8816

Kalafatis, S. P., Pollard, M., East, R., \& Tsogas, M. H. (1999). Green markering and Ajzen's theory of planned behaviour: A cross-market examination. Journal of Connsumer Marketing, 16(5), 441-460. doi:10.1108/07363769910289550

Kong, W., Harun, A., Sulong, R., \& Lily, J. (2014). The influence of consumers perception of green products on green purchase intention. International Journal of Asian Social Science, 4(8), 924-939.

Lau, R. (2017). Push for Electric Cars with BMW's i Wallbox at CityOne. Retrieved from Borneo Post Online: https://www.theborneopost.com/2017/09/05/push-for-electric-carswith-bmws-i-wallbox-at-cityone/

Lehman, P. K., \& Geller, E. S. (2004). Behaviour analysis and environmental protection: Accomplishments and potential for more. Behaviour and Social Issues, 13, 13-32. doi:10.5210/bsi.v13i1.33

Mahesh, N. (2013). Consumer's Perceived Value, Attitude and Purchase Intention of Green Products.

Medelson, N., \& Polonsky, M. J. (1995). Using strategic alliances to develop credible green marketing. Jounal of Consumer Marketing, 12(2), 4-18. doi:10.1108/07363769510084867

Meghanathan, N. (2016). Assortativity Analysis of Real-World Network Graphs based on Centrality Metrics. Computer and Information Science, 9(3). doi:10.5539/cis.v9n3p7

Monkelbaan, J. (2011). Trade preferences for environmentally friendly goods and services.

Moisander, J. (2007). Motivational complexity of green consumerism. International IJC, 31(4), 404-409. doi:10.1111/j.1470-6431.2007.00586.x

Morel, M., \& Francis, K. (2012). Green marketing: Consumers' Attitude towards Eco-friendly Products and Purchase Intention in the Fast Moving Consumer Goods (FMCG) sector.

Okada, E. M., \& Mais, E. L. (2010). Framing the "Green" alternative for environmentally conscious consumer. Sustainability Accounting, Management and Policy Journal, 1(2), 222-234. doi:10.1108/20408021011089257

Paco, A. M., \& Raposo, M. (2009). "Green" segmentation: An application to the Portugese consumer market. Marketing Intelligence \& Planning, 27(3), 364-379. doi:10.1108/02634500910955245

Peattie, K., \& Charter, M. (1992). Green marketing. The marketing book, 726.

Shell. (2019). Sarawak Delivers First Renewable Energy Certificate. Retrieved from Shell: https://www.shell.com.my/media/2019-press-releases/sarawak-delivers-firstrenewable-energy-certificate.html

Steg, L., \& Vlek, C. (2009). Encouraging pro-environmental behaviour: An integrative review and research agenda. Journal of Environmental Psychology, 29(3), 309-317. doi:10.1016/j.jenvp.2008.10.004

Wang, L., Wong, P., \& Narayanan, E. A. (2019). The demographic impact of consumer green purchase intention toward green hotel selection in China. Tourism and Hospitality Research, 0(0), 1-13. doi:10.1177/1467358419848129

Wiid, J., \& Diggines, C. (2010). Marketing Research. Juta \& Company Ltd. 
INTERNATIONAL JOURNAL OF ACADEMIC RESEARCH IN BUSINESS AND SOCIAL SCIENCES

Vol. 11, No. 8, 2021, E-ISSN: 2222-6990 @ 2021 HRMARS

Zikmund, W. G., Babin, B. J., Carr, J. C., \& Griffin, M. (2010). Business Research Methods. In 8 (Ed.). 